\title{
非対称の伽藍構成を有するシヴァ教チャンディの成立過程について A STUDY ON THE FORMATIVE PROCESS OF SIVAISTIC CANDIS WITH ASYMMETRICAL LAYOUTS FOR THE TEMPLE COMPLEXES
}

\author{
小野邦彦* \\ Kunihiko ONO
}

\begin{abstract}
In view of the existing theories on the history of Central Java, this study first re-examined the completion date of the ruins constructed mainly between the basin and the plain in the southern part of the area, which are believed to be the oldest among the Sivaistic candis with asymmetrical layouts for their temple complexes. Second, the author compared the styles of architecture used between the fore-mentioned sivaistic candis, and the Sivaistic candis whose remains are to be found in the northern mountainous areas of Central Java. As a result of this examination, it is now believed that what probably happened is that the moldings, bases and plan layouts seen in the Sivaistic candis found in the mountainous areas in the northern part went through a succession of changes and that they made their way into the region of the southern part. As a result of these changes, Sivaistic candis with features of such new styles of architecture as semi-circular cornices, plain bases and asymmetrical layouts for the temple complexes came to be in the southern part of Central Java by $732 \mathrm{AD}$ at the latest.
\end{abstract}

keywords: Java, candi, Sivaism, asymmetrical layouts for the temple complexes, semi-circular cornice, plain base ジャワ, チャンディ, シヴァ教, 非対称の伽藍構成; 半円繰形, 平滑型基壤

\section{1.はじめに}

西紀後初期の数世紀の間に,インド文化の潮流はインドネシア群 島の沿岸を洗い始め, その後 8 世紀前半頃から 16 世紀前半頃まで にかけて, ジャワ島を中心とするインドネシア群島には, インド文 化を源泉とする，いわゆる「ヒンドゥー・ジャワ文化」が興隆して いる。その文化の下に創出された美術遺品の中で, インド起源の宗 教, すなわちヒンドゥ二教と仏教の神仏を祀る宗教建造物は, 一般 にチャンディ（candi）と総称されている。

中部ジャワ期（8 世紀前半頃〜 10 世紀前半頃）におけるチャン ディ造営の主たる舞台となった中部ジャワ地方一带は, 遺構の地理 的な分布状況から，次の二地域に分けることができる。まず第一の 地域は, プラフ山南麓のディエン高原やウガラン山西斜面など中部 ジャワ北部の山間地であり，なかんずくディエン高原には，ジャワ 最古とされる一群のシヴァ教の遺構が現存している。そして第二 に，中部ジャワ南部の河川（プロゴ河，オパック河）の流域に広が る肥沃な盆地ないし平野部を中心とする地域が挙げられる。

拙稿で既に述べたように，上記の第二の地域，すなわち中部ジャ ワ南部の盆地ないし平野部を中心とする地域には,一見して左右対 称の伽藍構成を遵守しているようにみえて, 実際はわずかにその対 称性が崩されているシヴァ教の寺院建築遺構が集中して残されてい
る(1)。囲繞壁内に適宜配置された祠堂群が, 敷地の中心から若干ず らされることによって，伽藍は微妙に非対称となる。以下，このよ うな伽藍構成を「非対称の伽藍構成」と呼ぶことにする。

しかしながら，非対称の伽藍構成を有するシヴァ教チャンディ が, いつ頃、いかなる発展過程を経て成立したのかという問題を検 証する試みは従来皆無に近い。この問題を考察する際に問題となる のは, 肝心の中部ジャワ史には諸説あっていずれも定説たりえてい ないために, チャンディの建立期に対する編年論む研究者によって 結論が大きく異なることである。さらに, ディエン高原のシヴァ教 の遣構群をジャワ最古のものとみるのは従来からの定説である一方 で, それらが発達南下して中部ジャワ南部の地に新たな展開をみせ たのか, あるいは中部ジャワ北部とは系統の異なるシヴァ教寺院の 建築様式が, 中部ジャワ南部において並行的に展開したのかという 問題に対する考察も十分に行われているとは言い難い(2)。

従って本稿では, 先ず, 中部ジャワ史に関する従来の諸説に鑑み ながら, 非対称の伽藍構成を有するシヴア教寺院の内, 最初期のも のと考えられる遺構の建立年次の再検証を行う。次に, 中部ジャワ 南部を中心に造営されたそれらのシヴァ教寺院と, 中部ジャワ北部 のシヴァ教寺院の建築様式とを比較対照した上で, 前者の寺院建築 様式が成立するに至った経緯の一端について明らかにしたい。 


\section{2. 中部ジャワ期のシヴァ教寺院にみる非対称の伽藍構成}

非対称の伽藍構成を有するシヴァ教寺院の内, 中部ジャワ期に造 営されたものとして, チャンディ・サンビサリ (Candi Sambisari), チャンディ・ロロ・ジョングラン (Candi Loro Jonggrang), チャ ンディ・グヌン・ウキル (Candi Gunung Wukir), チャンディ・ グヌン・サリ (Candi Gunung Sari), チャンディ・イジョー (Candi Ijo), チャンディ・バドゥ (Candi Badut, 所在地 : 東部ジャワの マラン近郊）が挙げられる。ここで先ず，上記の遺構の伽藍配置に 認められる特質について確認しておきたい。

ほぼ正方形から成る囲繞壁によって取り囲まれた敷地の中央に は，ヒンドゥー教シヴァ派のシンボルとされるリンガ・ヨーニない しシヴァ神像を安置する最も大きな阔堂 (以下, 主䄇堂と呼ぶ) が 西ないし東面して配置され，またそれに正対して三基の建物が配置 される(3)。三基の建物には，シヴァの乗り物である聖牛ナンディン の像や, 小型のリンガ・ヨー二等の安置されていたことが確認され ているので，以下，それらの建物を副峝堂と呼ぶ(4)。図2 のチャン ディ・サンビサリは，主阔堂が西面する事例である(5)。

主祠堂及び三基の副祠堂は, 東西に走る中央軸を持ち左右対称形 に配置されるが，囲繞壁に取り囲まれた敷地の中央軸線上にはな く，全体に北側へずれて配置される傾向が認められる(6)。敷地の中 心点は, 主柌堂の正面階段翼壁と基壇の交差する隅の部分に一致 し, またその地点に, 十文字の刻線が記された特種な切石やリンガ 状の立石等が置かれる事例も認められる(7)。敷地中心点が重要な地 点として聖別され，その地点を避けるべく注堂群がずらされている 可能性が考えられる。さらに囲繞壁から等距離離れてほぼ正方形を なすライン上には，リンガ状の境界石等の指標物が，一辺につき三 個ずつ, 計八個配置されて結界を作っていると考えられる(8) (図2)。

敷地中心点を避けて柌堂群をずらすことの理由は, インドに由来 するヴァーストゥプルシャマンダラの観念に求めることも可能であ るが，その問題について詳しくは拙稿を参照されたい(9)。

一一方, チャンディ・サンビサリにおいては，囲繞壁の外郭を $32 \times$ 32 （=1,024）に分割するグリッドに従って，各祠堂の規模及び配 置，そしてリンガ状の境界石の配置が定められ，またグリッドの基 準格子の一辺の長さは, 祠堂群のずらし幅に等しいと推測される点 についても拙稿で述べた通りである(10)。サンビサリ以外の類例に， 同じくグリッドに基ゔく配置計画法が用いられていたのかどらかと いう開題については, 今後の研究を俟たねばならない。しかしなが

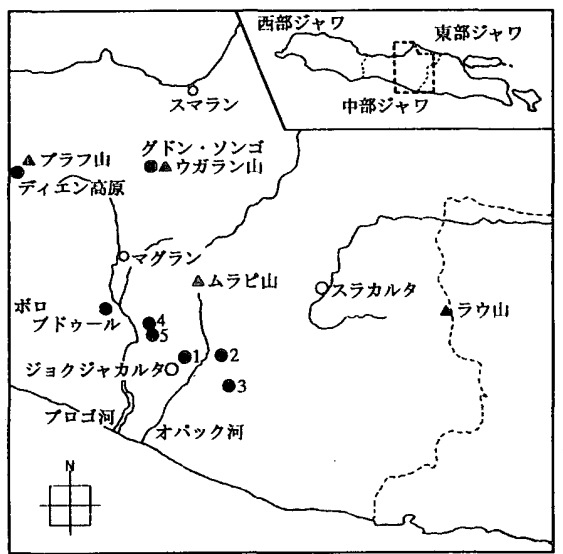

図1中部ジャワ要図
ら，囲繞壁及び境界石等の指標物で二重に結界された敷地内に，主 润堂及び三基の副祠堂を配し, また敷地中心点が, 主秱堂の正面階 段翼壁と基壇の交差する隅の部分に一致するという伽藍の基本的な 構成は, 他の類例にも共通して認められるむのである。さらに, 囲 繞壁の変更や副晑堂の増設等を裏付ける証跡に関する報告が今日ま で確認されない点を併せて考慮すれば，上記六例のシヴァ教寺院に おける囲繞壁, 主阔堂, 副柌堂は, 同時期に創建された可能性が高 いものと考えられる。

中部ジャワ南部に現存する比較的規模の大きいヒンドゥ一教チャ ンディの殆どが上に列挙されていることにより,これらの遺構にみ る非対称の伽藍構成は, 中部ジャワ南部に造営されたヒンドゥー教 チャンディを特徴付ける配置型式であると考えられる(11)。またこの ような伽藍の基本的な構成は, 後の東部ジャワ期のシヴァ教チャン ディにも継承されている点が特筆される(12)。

\section{3. 中部ジャワ期におけるチャンティの造営と史的背景}

今日までの碑文研究の成果によって, 8世紀以後の中部ジャワを 支配していた統一王朝については, 結論的に, ヒンドゥ一教徒（特 にシヴァ教）のサンジャヤの王統及び大乗仏教徒（特に密教）の シャイレーンドラ王朝という二つの政権の存在を認める説が有力で ある。先ず, プロゴ河流域を中心とするクドゥ南部地域から出土し た西紀732年の碑銘を有するチャンガル碑文と, 同じくクドゥ南部 出土の907年の銘ある碑文の二つにより，サンジャヤと称する王を 始祖とし,シヴァ教を信奉する王国が中部ジャワ南部に存在してい たことが知られる。次に, シャイレーンドラの名が登場する最初の 碑文は, オパック河の流域平野を中心とするプランバナン地域近傍 のカラサンから出土した778年の銘ある碑文であるが, 同じくプラ ンバナン地域のクルラクからも 782 年の銘ある碑文が出土してお り，その碑文にもシャイレーンドラの名がみえることにより，8世 紀後半には仏教を奉じるシャイレーンドラ王朝が中部ジャワ南部に

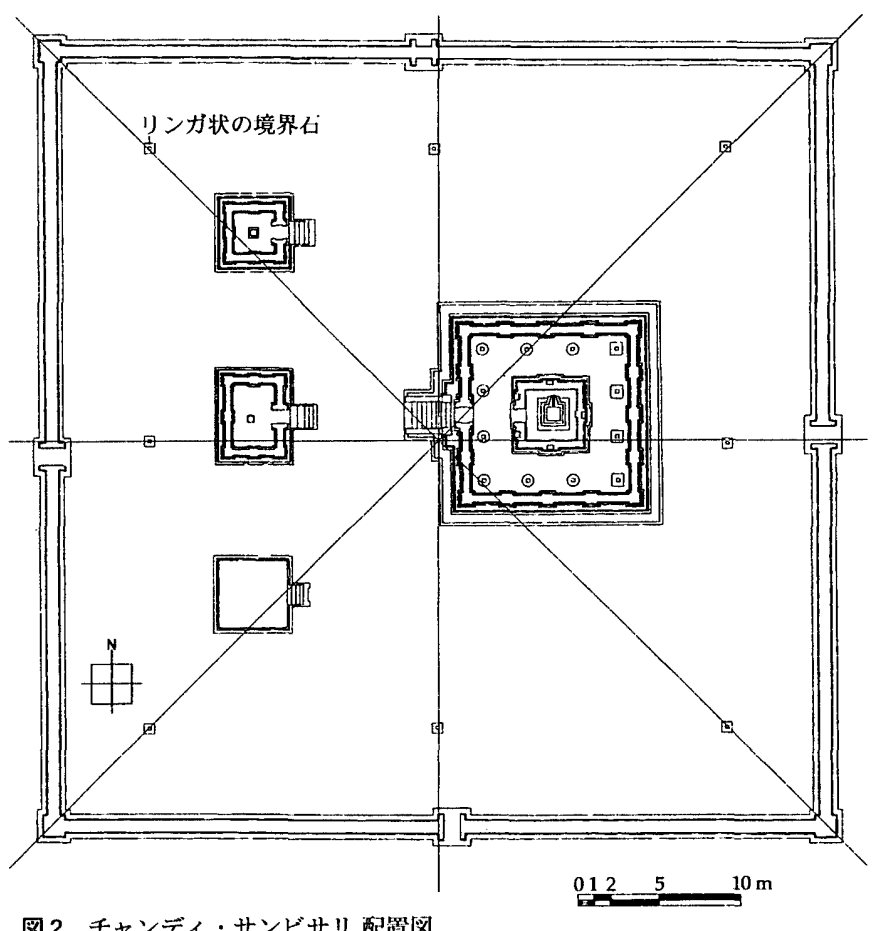

図 2 チャンディ・サンビサリ 配置図 
存在していたことが確認される。また,シャイレーンドラの名を伝 える三碑文が，ジャワ以外の地からむ発見されている。

ドゥニカスパリスは，上記の碑文以外に新たな史料を加えて詳細 な検討を行い, シャイレーンドラ王朝とサンジャヤ王統との関係に ついて新しい一石を投じている(13)。その論旨を要約すれば，次のご とくである。

先ず 8 世紀の前半には，クドゥ南部を中心にサンジャヤ王が勢力 を持っていたものの，8世紀の後半にはシャイレーンドラ王朝が中 部ジャワ南部に霉権を確立することになる。サンジャヤの王統は, クドゥ南部へと進出したシャイレーンドラ王朝に次第に押され気味 となり，第三代のパヌンガラン王（780 年頃 -800 年頃）の治世以後 は, 主として中部ジャワ北部の経営に集中するようになる。しかし 832 年頃までには, それまでシャイレーンドラ王朝に対して従属的 な立場に甘んじていたヒンドゥ一教勢力がその支配から脱し, 婚姻 による両王朝の融合にもイニシアティヴを取った結果, シャイレー ンドラ王朝の権威は消滅し, 中部ジャワ南部は再びサンジャヤ王統 の支配するところとなる。

以上のドゥ=カスパリスの説を支持するデュマルセは, 中部ジャ ワ南部がシャイレーンドラ王朝の支配下にあったと推測される780 年頃から832年頃までにかけて, ヒンドゥ一教チャンディの造営活 動は中部ジャワ北部においてのみ行われたと類推した上で, 中部 ジャワ南部に現存する主要なヒンドゥ一教の遺構を, いずれも832 年以後, つまりシャ.イレーンドラ王朝の勢力没落後に建立された チャンディとして位置付けている(14)。

ドゥニカスパリスの説が, ともすれば異宗を信奉する二王朝の対 立的な関係を軸に論証されていたものであったのに対して，ヨル ダーンは, 中部ジャワ南部における, 二王朝の平和的な共存・共栄 と二宗教の混淆とを主張している(15)。ヨルダーンが，この説を提示 する際にとりわけ注目しているのは, 先述のクルラクで発見された 碑文である。この碑文には，東ベンガルから来たとされる師僧に よって文殊師利の像が奉献されたことが述べられており，また「こ の高貴な持金剛はブラフマー神であり, ヴィシュヌ神であり，マ ヘーシュヴァラ神 (シヴァ神) であり，一切の神々を含んだもので ある」との一節が認められる。石井氏は，この碑文のいら文殊を「持 金剛」の文殊, 即ち密教の文殊師利に比定し，そしてヒンドゥ一教 の三主要神さえもが，「仏智」の顕れとして認識されていたと考え られる点について言及している(16)。

782年の年次を刻むこの碑文に，仏教とヒンドゥー教の意識的な 混淆ないし融合が看取される点からみても，8 世紀末以後の中部 ジャワ南部に, 二王朝が併存していた可能性は少なくとも否定され るべきではないと考えられる。例えば岩本氏は, 先述のカラサン碑 文の記述内容を改めて吟味した上で,二王朝相互の関連に係わる問 題についての従来の諸説に補訂を加えつつ，8 世紀の後半以後, シャイレーンドラ王朝はプロゴ河流域に広がるクドゥ南部地域に, またサンジャヤの王統はオパック河以東, すなわちその流域平野で あるプランバナン地域を中心とする領域にそれぞれ勢力を分け持っ て併存していたと考えられることを指摘している(17)。

以上のように，中部ジャワ期の二王朝の相互関係には諸説あっ て，いずれも定説たりえていないのが現状である(18)。千原氏も指摘 するように, このような中部ジャワ史の諸説が, ジャワ, スマトラ,
マライ半島,インドなどの各地で発見されている若干数の史料と中 国史書の記述とによって構筑された多くの仮説を包含するものであ る以上, 史的背景に多くを依存したチャンディの編年論には, 自ず から限界があるものといえよう(19)。現に，ドゥ=カスパリスの説を 基本として組み立てられたデュマルセによるチャンディの編年論に は，一部容認し得ない点も認められる。特に，780 年頃から 832 年 頃までを中部ジャワ南部に抢けるヒンドゥ一教勢力の完全なる空白 期とみなし，その時期に二王朝が中部ジャワ南部において併存して いた可能性を予め否定してチャンディの建立期を推定している点 は，再考を要するものと考える。

上記の留意点を踏まえながら, 以下, 非対称の伽藍構成を有する チャンディの内, 最初期の遺構に属するとみられるチャンディ・グ ヌン・ウキル及びチャンディ・バドゥの建立年次について, デュマ ルセを含めた諸氏の見解を改めて検証することにしたい。

\section{4. チャンディ・グヌン・ウキルの建立年次の再検証}

チャンディ・グヌン・ウキルは, クドゥ南部のチャンガル村付近 のウキル丘上に建立されたシヴア教の遺構である。グヌン・ウキル の伽藍には，他の非対称の伽藍構成を有するチャンディと同様に， リンガ・ヨーニを安置する主祠堂と, それに正対する三基の副柌堂 が配置されている（図 3)。これらの闹堂群を取り囲む煉瓦造の囲 繞壁は現在埋め㞍されているために, 現状の遗構から洞堂群の「ず らし」を確認することはできない。しかしながら, グヌン・ウキル の敷地中心点が避けられていたことは, スクモノ及びバーネット= ケンペルスによって確認されている(20)。

同遺構の建立年次については諸説あるのが現状であり，例えば フォグラーは, チャンディの装飾細部としてもっとも普遍的なカー ラ・マカラ装飾 (出入口や萮の額縁の装飾意匠に用いられるモチー フ）の形態を比較対照して諸遺構の編年を試みた上で, グヌン・ウ キルの建立年次を928年以後に位置付けている(21)。グヌン・ウキル の建立年次を巡って常に論議の対象とされるのは, 先述のチャンガ ル碑文の記述である。碑文はその書き出しにおいて, サンジャヤ王 が 732 年に山上にリンガを建立せしめたと記している(22)。しかし フォグラ一は, 碑文の発見地がグヌン・ウキルの寺苑から南へ150 メートルの地点と距離的に離れすぎているとして, グヌン・ウキル の建立年次と碑文の記述とを関連ゔけることを否定している(23)。

それに対しスクモノは,フォグラーが得た碑文の発見地に関する 情報は, 1937 年に近隣の村民から得た伝聞を根拠とするものに過 ぎず，情報としての信頼性に欠ける点を指摘している(24)。チャンガ ル碑文は, 元々 1879 年にグヌン・ウキルの門の傍から発見されて いることがクロムによって指摘されており ${ }^{(25)}$ ，また当時の古代遺 跡・遺物目録にもそのように記されている(26)。さらにスクモノは， チャンガル碑文の欠損部分が，1937 年にグヌン・ウキルの寺苑内 から発見されていることを指摘した上で, 碑文の内容とグヌン・ウ キルの建立との関連は明らかであると結論付けている(27)。また, グ ヌン・ウキルは小丘の頂部に建てられており, その立地は「山上に リンガを建立せしめた」との碑文の記述に符節するものである。

チャンガル碑文は, 年次を有する碑文としてはジャワ最古とされ るむのであり, ここでスクモノの説に従うならば, グヌン・ウキル は, 中部ジャワ南部に現存する全てのチャンディの中で, 最初期の 

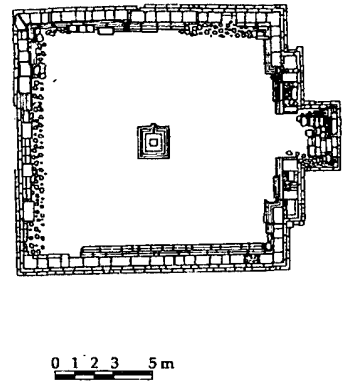

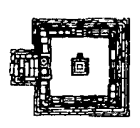

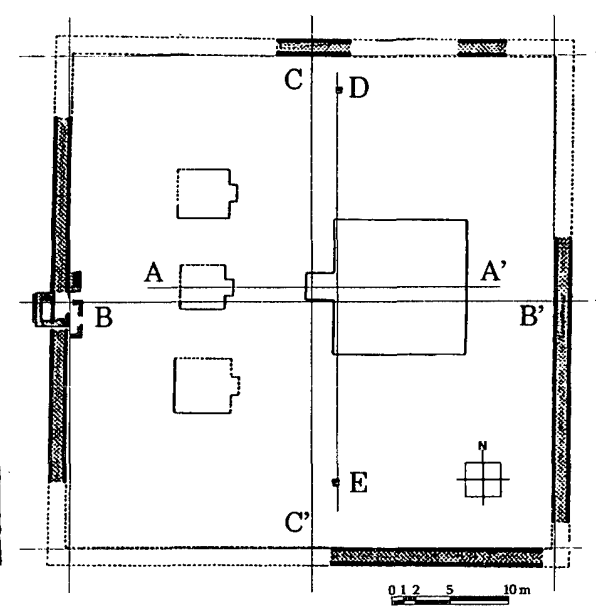

図4 チャンディ・バドゥ配唯図（オランダ頜東インド 考古局による)

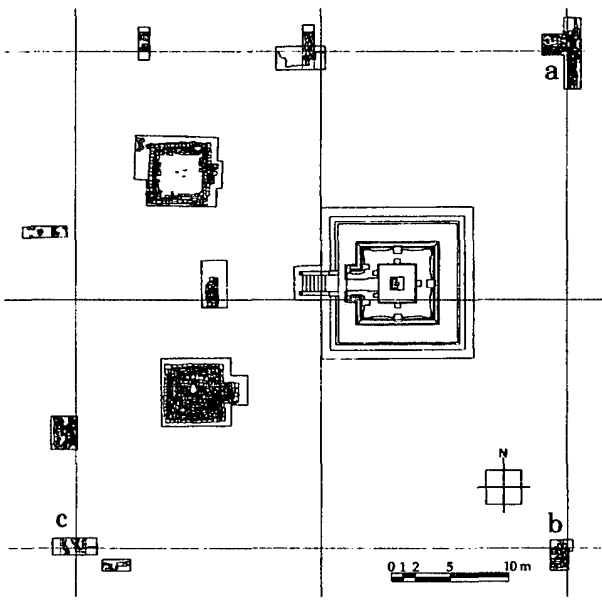

図 5 チャンディ・バドゥ配置网 (インドネシア教育文 化省東部ジャワ州事務所による)
遗構に該当することになる。グヌン・ウキルの建立年次を，碑文に 銘記された732年に比定するスクモノの解釈には千原氏む同調して 抢り，また千原氏は，カーラ・マカラ装飾にのみ限定して建筑の編 年を試みるフォグラーの方法の限界をむ同時に指摘している( ${ }^{28)}$ 。

しかし一方で, 先のフォグラーの説に同調するデュマルセは, グ ヌン・ウキルの建立年次を 832 年以後の間むない時期に位置付けて いる(29)。このことに関連してデュマルセは, ボロブドゥール造営の 第 2 期（782 年頃～ 792 年頃）に認められる，垂直面に僅かな相決 りを施して重䄈られる切石積みの工法が，グヌン・ウキルにも用い られている点について言及している(30)。しかしチャンディ・セウ造 営の第一期（760 年代後半頃 778 年頃）において既にその工法が 認められる点は，デュマルセ自らが指摘していることでもある( 従って, グヌン・ウキルがボロブドゥールの切石積み工法を踏襲し て，782 年以後に造営されたとは必ずしも断じ得ないはずである。

またデュマルセは，隣接する数個の石の間隙に楔石を打ち込ん で, 周辺の石同士を緊密に結合させる切石積み工法が, 前述のサン ビサリには頻用されているのに対して，グヌン・ウキルにはその工 法が用いられていない点を指摘している( ${ }^{(92)}$ 。さらに, グヌン・ウキ ル及びサンビサリには, ロロ・ジョングランやイジョー等に認めら れる, 二重の安山岩の化粧材の内部を火山性凝灰岩で充填する壁工 法が用いられていない点についても言及している( ${ }^{(3)}$ 。

このように, グヌン・ウキルが比較的古い工法で筑造されている とみられる点に鑑みれば, グヌン・ウキルの建立とチャンガル碑文 の内容との関連を是認し, グヌン・ウキルを中部ジャワ南部で最も 古い型の遺構とみなすことに, 本来大きな問題はないものと思われ る。にもかかわらずデュマルセが，グヌン・ウキルと碑文の内容と の関連を否定するのは, グヌン・ウキルに括ける非対称の伽藍構成 を，832年以後のヒンドゥ一教勢力の復興に伴ってインドから将来 された新しい配置型式とみているからであると考えられる( ${ }^{(34)}$ 。

しかしながらその見解は, 先に述べたドゥ=カスパリスの説から 類推された一つの憶説に過ぎず, 具体的な根拠に基づいて実証され ているものではない。すなわち，その推測のみをもって，グヌン・ ウキルと碑文の内容との関連を否定するのは, 根拠が不十分である といわざるをえない。上記の諸点に鑑みて素直に解积すれば，グヌ ン・ウキルの建立年次は，チャンガル碑文に銘記された 732 年とす るのが，最も妥当であると考えられる。

\section{5. チャンディ・バドゥの建立年次の再検証}

東部ジャワのマラン近郊に現存する中部ジャワ期の遺構として知 られるのがチャンディ・バドゥである。バドゥの伽藍には, リンガ・ ヨ一二を安置する西面する主柌堂と，それに正対する三基の副䄇堂 が配置され，それらをほぼ正方形をなす囲繞壁が取り囲んでおり， また祠堂群は北側にずれて配置されているのが確認される（図5）。 ところで，マラン近郊のディノヨからは，760 年の銘のある，い わゆるディノヨ碑文が出土している。碑文にみえるアガスティア （尊師の姿をとるシヴァ）に捧げられた建造物を，バドゥと同定す るか否かについて，カーラ・マカラ装飾を編年の資とする既述の フォグラーは，遺構と碑文の発見地とが離れすぎていると疑問視 し, 結果, バドゥの建立年次を中部ジャワ期の最末期（10世紀初 め頃）に位置付けている ${ }^{\left({ }^{35)}\right.}$ 。他方スクモノは，バドゥの建築全体の 様式が中部ジャワ期の古い型を基調とするものであり，また造営第 一期のチャンディ・カラサン（778 年）やチャンディ・グヌン・ウ キルと同様に,バドゥが繰形や浮彫りを一切有しない平滑な断面か らなる基壇を持つことからみて，760年をそのまま建立年次とする のは無理とはいえ，8世紀中頃の建立とすべきとの見解を示してい る(36)。また千原氏む，このスクモノによる解粕に同調している( ${ }^{(37)}$ 。

しかし一方でデュマルセは,バドゥとディノヨ碑文との関係を大 筋で認め, バドゥの建立年次を 8 世紀中頃とする解釈を認めるもの の，9世紀に入りその伽藍配置には変更があったと推測している。 デュマルセによれば，創建期のバドゥは，中心線 AA'-CC'（図 4) からなる方形の伽藍を有していたのに対し, 寺院敭地の中心点を避 けるべく囲繞壁が改変され，中心線 BB'-CC'からなる伽藍が新たに 創出されたという(38)。なお，D及びEの籄所に置かれているものは， 上部中央に正方形の穴が穿たれたおよそ $50 \mathrm{~cm}$ 四方の切石である( ${ }^{(99)}$ 。

しかしながら既述のように, 囲繞壁の改変を裹付ける証跡に関す る報告は今日までないといらのが実情である。また筆者が現地で測 量を行って検証した結果, オランダ領東インド考古局によって作成 された図4は，インドネシア教育文化省東部ジャワ州事務所による 図 5 （原図の縮尺が 1/100）と比べ，十分な精度を有するものでは ないことが確認された。両図を比較すると，敖地中心点や副䄇堂の 位置関係が相当異なっていることが理解される。すなわち，建築学 的な分析に必要な精度を有しない図 4を根拠として, 囲繞壁の改変 の有無を論議すること自体に問題があるといわざるをえない。 
また図5を見ると,バドゥの敨地中心点は, 主柌堂の正面階段翼 壁と基壇が交差する隅の部分にほぼ一致しておりり尔，これは他の類 例にも共通して認められる特徴であることは既に指摘した通りであ る。さらにこれらの遺構の伽藍には, いずれもシヴァを祀る主祠堂 に正対して三基の副祠堂が配置されている他, バドゥの敫地の南北 から出土した台座状の切石（図4のD，E）は，チャンディ・サン ビサリ等の寺院啺地の四方四維に位置する地点に配せられた, 結䀘 を示す指標物に類するものとみることが可能である。すなわち, 他 の類例に認められる伽藍配置上の特質が, そのままバドゥにも共通 して認められる点に鑑みれば,バドゥがその創建時において，既に 非対称の伽藍構成を有していたとみなすことには少しの不合理むな い。さらに，732 年の建立と推測されるグヌン・ウキルにおいて， 既に非対称の伽藍構成が認められるのであるから, 追って8世紀中 頃に建立されたと推測されるバドゥにも,グヌン・ウキルと同様の 配置型式が用いられたと考えることに矛盾するところはない。

\section{6. 中部ジャワ北部山間地のシヴァ教寺院との比較}

6-1. ジャワのシヴァ袷堂の祖型としてのチャンディ・アルジュノ

ジャワのチャンディの編年論仕, 研究者によって結論が大きく異 なるのが実情であるが，ディエン高原のチャンディ・アルジュ， (Candi Arjuna) をジャワ最古の遺構とみる点に限り, 大方の研究 者の見解は共通している(4i)。アルジュノが最も基本的な型式からな る峝堂であると考えられることは，千原氏によってすでに指摘され ている(42)。この点について改めてまとめてみると，まずその建筑構 成は, 最下層の台状の基㒄の上に函状の身舎を載せ，さらにその上 に載る迫出し構造からなる屋蓋牥，身舎の侧壁と同じ構成を持った 函形を段台状に数層積み上げたものとなっている（図 7)。身舎及 び屋蓋の段台の各層の軒先の四隅には，宝冠状のラトナと称するユ ニットが配せられる。また現在は消失しているものの, 屋蓋の最頂 部にもラトナが配せられていたと考えられる。身舎は正面にのみ入 り口をむち, 内陣にはリンガ・ヨーニが安置され，また入り口の両 脇と残り三方の壁体外面の中央には壁䧻吕付され，またその中に， 現在は消失しているむのの, 各々一体ずつの尊像が安圈されていた と考えられる。そして入り口や愈の頂部には，カーラと称する鬼面 像が，またそれらの朢枠の下端には，マカラと称する像が浮彫りさ れている。ジャワのチャンディの大部分を占める祠堂の殆どは，そ の建筑構成, 細部意匠などいずれをとっても,アルジュノを祖型と する変化形とみることが可能である(4)。

\section{6-2. シヴァ泀堂の尊像配置にみる規範性}

中部ジャワの北部及び南部のシヴァ柌堂の主房及び壁弇(ないし 側・後房) に安置される彫像の配列にも, 共通の原則が看取される。 中部ジャワ北部， ウガラン山西斜面のグドン・ソンゴ（Gedong Songo)の第三コンプレックスの主悯堂の身舎に穿たれた壁閦には 愿肉浮彫りの像が残っており, まず, 正面入り口右の㴰にはマハー カーラ, 左にナンディーシュヴァラ, 背面 (東) の毹にガネーシャ, 北にドゥルガー, そして南にアガスティアの像が各々安置されてい る。これらシヴァの変化相ないしその眷属の像の配置は, シヴァ茼 堂に抒ける尊像の典型的配置とされるものであり，この後チャン ディ・ロロ・ジョングランのシヴァ祠堂を始め, 非対称の伽笽構成 を有するチャンディのシヴァ萂堂にもこの尊像配置の原則が用いら
れている(44)。

ディエン高原のシヴァ祠堂において, 既に上記の尊像配置の原則 が認められたのかどうかは明らかではない(45)。なぜなら，チャン ディ・スリカンディ (Candi Srikandi) を除く䄇堂の壁俞に安置さ れていた諸燢の像は現在すべて失われているからである。唯一，西 面するスリカンディの南・北・背面の側壁の中央には, ピラスター で仕切られた浮彫りの像が現存し, 北面のパネルには一面四臂の ヴィシュヌ, 南面には三面四䐴のブラフマーささらに背面 (東)に は一面四臂のシヴァが浮彫られている。こうした尊像の配列は, 先 述のシヴァ筒堂における尊像の典型的配置とは異なるものである が, 中央のシヴァの北側と南側に，それぞれヴィシュヌ及びブラフ マーを配する図像的な構想は, チャンディ・ロロ・ジョングランに 併秄された三尊の像を安置する柌堂の配置においても具現化されて いる(46)。

以上，中部ジャワの北部及び南部のシヴァ教の柌堂の建筑構成， 細部意匠, そして尊像の配列には，一貫した規範性を看て取れるこ とが改めて確認された。こうした原則が顥著に窥えることに鑑みれ ば, 中部ジャワの北部及び南部に各々営まれたシヴァ教寺院は, 基 本的に系統を同じくする建筑とみるのが妥当であると考えられる。

\section{6-3. 伽藍配置にみる相違点}

シヴァ神を祀るチャンディ・アルジュノは西面し，またそれに正 対して矩形平面を有するチャンディ・スマール (Candi Semar) が 配置されている（図 6)。シヴァを祀る主䄇堂に正対して矩形平面 の建造物が一基のみ配置される伽藍の構成は, グドン・ソンゴの第 ニコンプレックス, またディエンのチャンディ・スリカンディにむ 認められるものである（図 12）。加えてディエンのチャンディ・ブ ントデウォ (Candi Puntadewa) においては, 主祠堂の背後にさ らに一基の建造物が配置されており（図 12），またグドン・ソンゴ の第三コンプレックスは, 主峝堂の両側にさらに二基の副阔堂を配 置する伽藍構成を有している。シヴァ柌堂の正面に建造物が一基の み配置される伽藍の構成は, 中部ジャワ南部のシヴァ教寺院には確 認されないむのである。既述のように, 非対称の伽藍構成を有する シヴァ教寺院の場合, 主祠堂に正対して配㯰される副洞堂の数は三 基となる。

アルジュノの正面に配㯰されたスマールの宗教的性格については 明らかではないものの, デュマルセは, シヴァの乗り物であるナン ディンの像が, 創建時のスマールの内陣に安置されていたと推測し ている(47)。シヴァ祠堂の正面にナンディンを祀る副䄑堂を配する祠 堂の配列は, 非対称の伽藍構成を有する寺院でも確認される ${ }^{(48)}$ 。さ らにアルジュノの伽藍で特筆されるのは, 東西に走る中央軸を持つ 二基の祠堂が, 囲繞壁で取り囲まれた寺院敷地のほぼ中軸線上に左 右対称に配置されている点である（図6)。すなわち，非対称の伽 藍構成を有するシヴァ教寺院は,スマールの両側に二基の副祠堂を 配し，また敖地中心点を避けるべく祠堂群がずらされるなど，アル ジュノの伽藍配置が一段と発展したものとみることが可能である。

一方,アルジュノに近接するプントデウォの伽藍は, 短辺に比し て長辺がかなり長い矩形となっており，また囲繞壁と阔堂は平行に 配せられていない(図12)。その伽藍は左右対称形にはならないが, これまでに筆者が論じてきた中部ジャワ南部のシヴァ教寺院にみる 非対称の伽藍構成とは明らかに異なっている。 

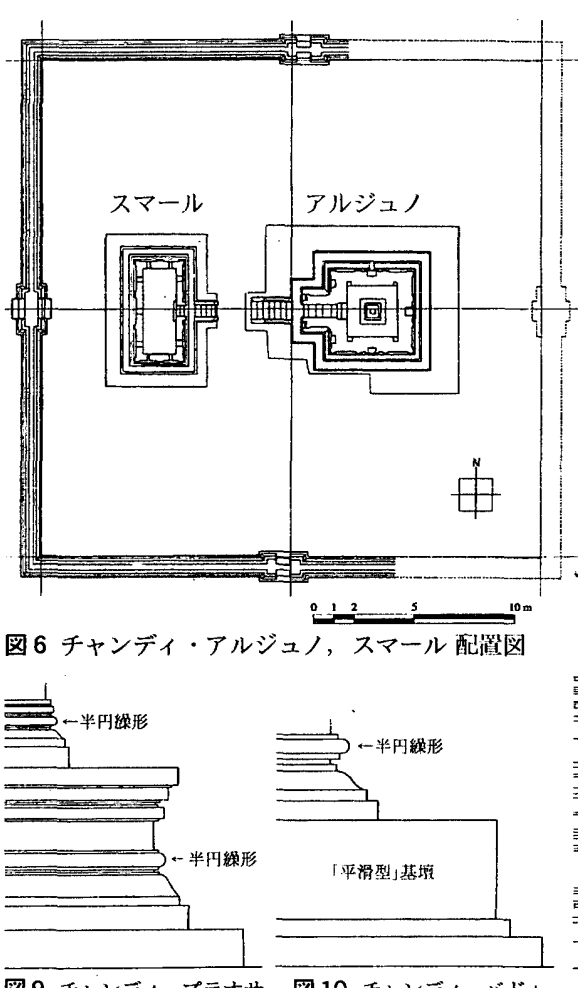

図 9 チャンディ・プラオサ ン・ロル主泀堂の基域及び 舍脚部のモールディンダ

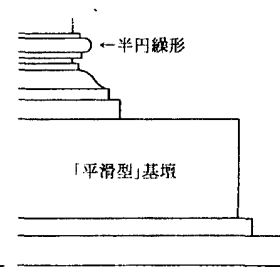

図 10 チャンディ・バドゥ の基烄及び身舎脚部のモー ルディング

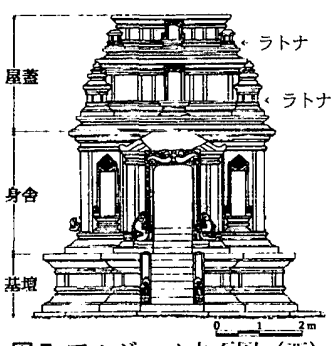

图 7 アルジュノ立自图(晒)

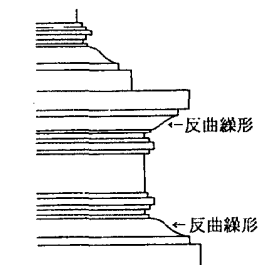

图8アルジュノの基坮及で 身舎嘣部のモールディング 半繦㔙

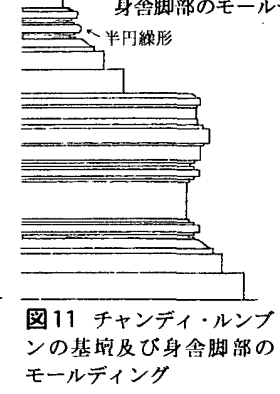

モールディング

荒廃甚だしいジャワのチャンディの中にあって, 中部ジャワ南部 に現存する主要なヒンドゥ一教寺院の殆どが非対称の伽藍構成を有 するものであり, またその侞藍構成は, 後代の東部ジャワ期のシ ヴァ教寺院にむ継続して用いられているという点を考慮すれば, 古 式を残すとされるディエンの遺構における上記の伽藍配置は, 中部 ジャワ南部のシヴァ教寺院にみる非対称の伽藍構成が成立する以前 の配置型式であると推測される(49)。

\section{6-4. モールディング構成及び基壇型式にみる相違点}

チャンディの基壇のモールディング構成についてむ,アルジュノ は祖型とみるに相応しい特徴を備えている。まず, ベース及び上端 の持ち送り部分が凸形反曲状に象られ (以下、反曲繰形と呼ぶ)，ま たその間に挟まれた胴部の上・下端に, 直角断面からなる帯状の突 出部が挿入されている（図 8)。拙稿で既に述べたよ5に(50)，アル ジュノ以外の柌堂建筑の基壇のモールディング構成は, 帯状の突出 部分が半円状に彫り出されたり（以下，半円繰形と呼ぶ），あるい は装飾帯が挿入されるなど様々なヴァリエーションを持つが, 原則 としてアルジュノの基壇にみるモールディング構成を祖型とした上 での変化形としてみることが可能である。そして, こうした腰の括 れた造形からなるモールディングの構成は，基壇上の身舎側壁の モールディングにも共通して認められるものである。

しかしながら，グヌン・ウキル，バドゥ，サンビサリ，イジョー の基壇は, 浮彫りや繰形を一切持たない平滑な断面からなっており (図 10，以下，「平滑型」基壇と呼ぶ)，上述のモールディング構成 とは基壇の型式が異なっている。とりわけグヌン・ウキルは,「平 滑型」基壇が確認される最古のチャンディである点が特筆される。 さらにバドゥの「平滑型」基壇の上の身舎脚部には, 中部ジャワ北 部のシヴア注堂には殆どみられない半円状に彫り出された半円絽形 の認められる点が注目される（図 10）。従来の研究に㧤いて，半円

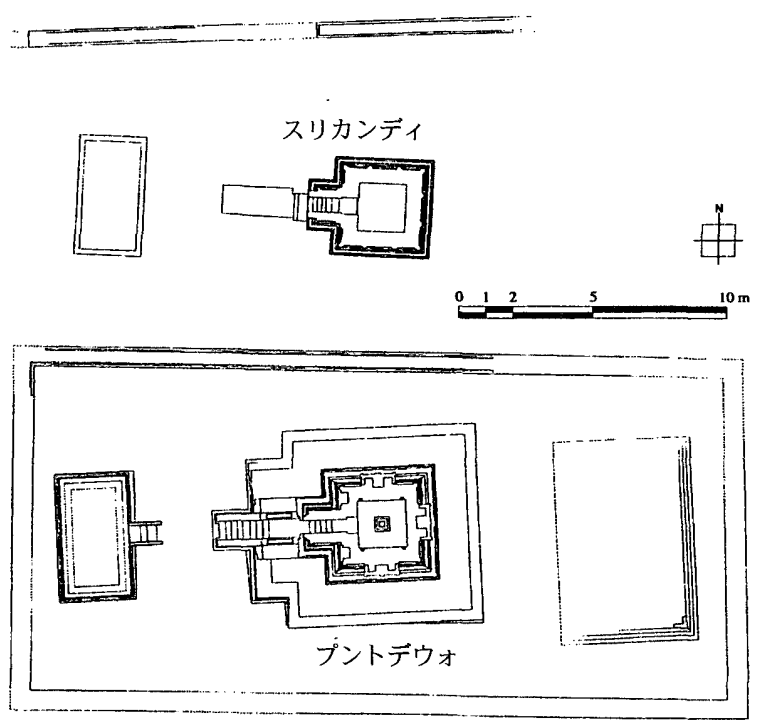

図 12 チャンディ・スリカンディ, プントデウォ配筧闵

繰形を有するモールディングの構成は, 仏教を奉じるシャイレーン ドラ王朝によってもたらされたむのとされているが(51), 半円繰形の 存在が確認される遗構として最古のものは, シヴァ教寺院のバドゥ である点に留意しなければならない。

千原氏は，上記のモールディング構成の中に，半円繰形のような 曲線断面, さらには歯飾りのような装飾带を有するタイプを「南方 型」(図9), そして反曲繰形以外には曲線断面の繰形を一切含まず, すべての凹凹が直角のみに終始しているアルジュノのようなタイプ を「北方型」と命名し，中部ジャワ期の主要なチャンディの基壇及 び身舎脚部のモールディングの類型化を行っている(52)。千原氏の研 究において, 中部ジャワ北部に現存する数多くのチャンディのモー ルディング構成が「北方型」，また中部ジャワ南部のチャンディの それが「南方型」を基調とするむのであることが明らかにされた点 は極めて重要である(59)。

そしてまた，「平滑型」の基壇がディエンやグドン・ソンゴのシ ヴァ䄇堂には認められない点を踏まえつつ, そのオリジンを「南方 型」系に属するものと位置付けた上で，「平滑型」基壇のみを残す グヌン・ウキルの身舎が, 半円繰形を有する「南方型」系のモール ディング構成からなっていた可能性について論じている点は注目に 值する ${ }^{(54)}$ 。筆者が現地で調查を行った際に，グヌン・ウキルの敷地 内に瓦啋状に堆積された元の建材の中から, 半円状に彫り出された 切石が散見されたことからむ, 千原氏の見解を推測として簡単に哌 けることはできないと思われる。

しかしながら，その二系統のモールディング構成が，いずれかの 方が古い型式で, 他はそれから発展したというのではない, すなわ ち,インドからの三つの異なる文化導入のルートの下に並行的に成 立したとする千原氏の立論(55)に対しては，筆者は意見を異にしてい る。筆者は，モールディング構成を含めて祖型とみるにふさわしい 中部ジャワ北部山間地の一群のチャンディが, 発達南下して中部 ジャワ南部の地に新たな展開をみせたものと考えている。

千原氏がモールディング構成の双系的な展開を論じる上で根拠と しているのは, 両系統の混用例, 例えば「北方型」の基壇の上に「南 方型」の身舎を載せるなどの遺構が存在しないという点である。し かし,クドゥ南部に所在するシヴァ教の稿堂であるチャンディ・ル 
ンブン（Candi Lumbung）は，半曲繰形以外には曲線断面を一切 含まない基壇(56)の上に，半円繰形を有する「南方型」系の身舎を載 せた建筑構成を有している(57) (図 11)。また「南方型」系とされる 「平滑型」の基壇を有するチャンディ・サンビサリの身舎には，「北 方型」のモールディング構成が確認される。

そして,アルジュノに代表される中部ジャウ北部のシヴァ教寺院 が，䄇堂の建築構成，細部意匠，尊像配置等の面で，中部ジャワ南 部のシヴァ教寺院の祖型とみるに相応しい特徵を顕著に備えている 点については既に指摘した通りである。こうした建築ないし美術の 様式上の一貫した規範性に鑑みれば, 半队繰形を有するモールディ ング構成及び「平滑型」の基壇は，祖型となる北部山間地のシヴァ 教寺院のモールディング構成及び基壇型式の発展型ないし変化型と 捉えるのが適当であると考えられる。また，半円繰形及び「平滑型」 基壇の確認される最古の遗構が，いずれも非対称の伽藍構成を有す るシヴァ教寺院である点は極めて重要である。半円繰形及び「平滑 型」基壇という新たなモールディング構成及び基壇型式の導入に 伴って，非対称の伽藍構成が創出されたとみるのが妥当であろう。 すなわち, 半円繰形, 「平滑型」基塯, そして非対称の伽藍構成は, 遮くとも 732 年頃（グヌン・ウキルの推定建立年次）までに，中部 ジャワ南部にもたらされた新たなシヴァ教の寺院建築にみる様式上 の特質であると考えられる(58)。

\section{7. 結び}

以上, 中部ジャワの北部山間地に造営された古式を残すシヴァ教 寺院にみるモールディング，基壇，さらには別藍の型式が，発達南 下して中部ジャワ南部の地に新たな展開をみせた結果，遅くとも 732 年頃までに, 非対称の伽藍構成を有するシヴァ教寺院が成立す るに至ったと考えられる点を指摘した。このような建筑様式にみる 変化ないし進展が, インドの新たな文化的な潮流を摂取した結果生 じたのか, あるいはジャワにおける自律的な発展の下に生じたのか という問題を検討することはできなかったが，この点については稿 を改めて論じることにしたい。

一方, 中部ジャワ北部から南部への単純かつ直線的な建勧様式の 発展という文脈では解积できない事例も存在する点には留意しなけ ればならない。例えばディエンには，いわゆるチャンディの基本型 から逸脱した特異な建築構成を有するチャンディ・ビモ（Candi Bima）のような祠堂も認められる。また, 中部ジャワ北部のスンビ ン山東麓には，「平滑型」基壇を有するチャンディ・プリガプス (Candi Pringapus) の存在が確認される。さらに，グドン・ソンゴ の第三コンプレックスの副祠堂は, 例外的に「南方型」のモールディ ング構成を有するむのである。この副䄇堂のカーラは, 後の東部 ジャワ期のものにみられるような下買を有するむのであり，中部 ジャワ期のカーラとしては稀な例であることからみて, 第三コンプ レックスの副祠堂は，後代に増設された建筑である可能性が高い。 すなわち, 北部山間地に営まれたジャワ最古のシヴァ教チャンディ が，発達南下して中部ジャワ南部の地に新たな展開をみせた後に， 再び北上して寺院造営活動を再開した可能性は考え得るし(59)，ある いは一旦南下した後であっても, 中部ジャワ北部の地に留まって寺 院の造営・運営に携わっていた勢力が残存していた可能性も考慮し なければならない。
謝辞

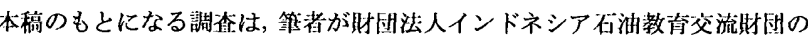

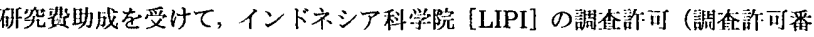
最: 4861/1//KS/1997) の下に，1996年7月から 1998年9月にかけてジャワ島 で行ったものである。また早稲田大学アジア建築研究会（代表中川武）が 1994作に文部省科学研究費 (国際学術研究) の助成を受けて行った调植研究 の成果む活用している。ここに記して，謝澺を表したい。

注

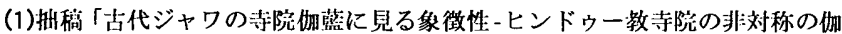

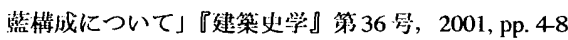

(2)この問題に関する千原氏による見解は，以下，本文において改めて検䣓を行 らものとする。

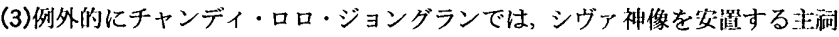

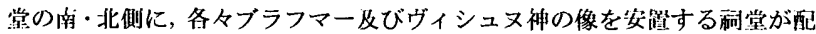

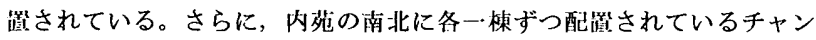
ディ・アピット(Candi Apit) と呼ばれる建物む，他に類例を見い什し得な い。その内，北侧の建物にはシヴァの神妃ドゥルガーの像が嫃されていた とみられる点が指摘されている (Jordaan, Roy E. ed, In praise of Prambanan: Dutch essays on the Loro Jonggrang temple complex, Leiden: KITLV Press, [Translation Series 26] , 1996, pp. 87-88)。

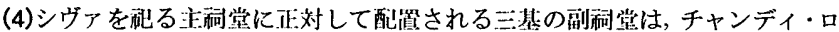
ロ・ジョングランのそれを除き，現地ではチャンディ :プルワラ (Candi Perwara プルワラは侍女の甞）と呼び贸わされている。副滀堂に㚣置され ていた神像等は，遗头している場合も多い。

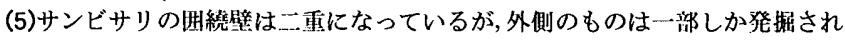
ておらず，その全体の形状は明らかではない。

(6)前揭䩀注(1)pp. 4-8, 12-13

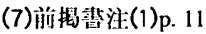

(8)羭接韭注(1)p. 12

(9)前揭拱注(1)pp. 13-17

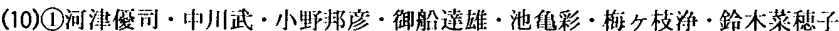

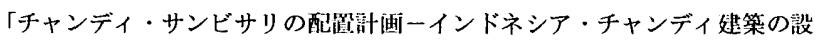
計方法の研究 (I ) J『日本建築学会大会学術請演梗概集』1995, pp. 543-544; (2)小野扼彦・河津俊司「インドネシア，ジャワ島のチャンディ」『アジアの 歷史的建造物の設計万法に関する笑測調查研究』(文部省科学研究救・研究

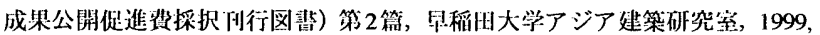
pp. 3439

（11)中部ジャワ南部の比較的規模の大きいヒンドゥー教の蛄構として，他にチャ ンディ・バロン (Candi Barong) が紫げられる。バロンの伽藍は, 段台状 に造成された三鮊のテラスから成るが, 最上段のテラスに二基の建造物が配 琵されるのみである。この他のヒンドゥ一教チャンディは, 苚堂一基のみか らなるとみられる小規模なものが多い。そして後に述べるように，非対称の 伽藍檴成は, 中部ジャワ北蔀のディエン及びグドン・ソンざの頲構群には見 認されない。また一方で，中部ジャワ南部の主最な仏教チャンディの伽藍は，

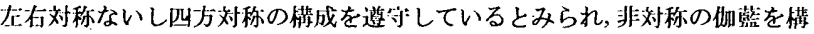
成するシヴァ教チャンディとは対照を成していると思われるが，网宗教の チャンディの伽鴜構成の詳細な此較考祭は稿を改めて行いたい。

(12)東部ジャワ期（10 世紀前半煩〜 16世紀前半頃）のヒンドゥー教チャンディ の内，チャンディ・キダル (Candi Kidal), チャンディ・ジャウィ (Candi Jawi)，チャンディ・ランドゥアグン (Candi Randuagung), チャンディ・ グラー (Candi Gurah) の四連構の伽藍が非刘称となることについては, 站 揭费注(1)pp.7-10を参照されたい。然るに，東部ジャワで最大の規模を溚る シヴァ教将院であるチャンディ・パナタラン (Candi Panataran) の伽藍に

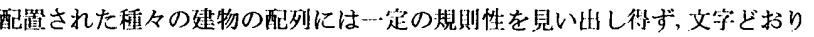
非対称の伽篮を造っている点は注目に值する。本稿で洘祭の刘像とする「非

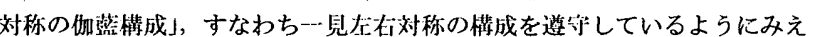
て，わずかにその刘称性が鼎されるものとは異なっている。さらに束部ジャ ワ期のヒンドゥー教チャンディには, 山腹から川四へ问けて, 数層のテラス

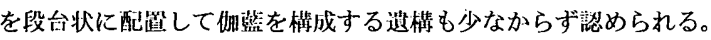

(13)Casparis, J. G. De, Inscripties uit de Çailendra-tijd, Bandung, 1950

(14)Dumarçay, J., Histoire de l'architecture de Java, Paris: École Française d'Extrême-Orient, [Mémoires Archéologiques 19] , 1993, p. 287

(15)Jordaan, Roy E., Imagine Buddha in Prambanan; Reconsidering the Buddhist background of the Loro Jonggrang temple complex, Leiden: Vakgroep Talen en Culturen van Zuidoost-Azië en Oceanië, [Semaian 7.], 1993; 前抱制注(3)pp. 3-115

（16)石非和子「『サン・ヒアン・カマハーヤーニカン (算大乘諭)』」にみる吉ジャ 
ワの密教」『東南アジア研究』27巻 1 号, 1989, p. 58

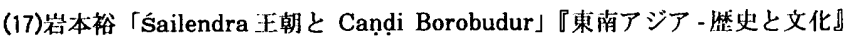
No. 10, 1981, pp. 17-21

(18)いずれにしても，中部ジャワ期のジャワに二王胡が存在していたとする説 が有力ではあるが，その一方で，中部ジャワ北等のプカロガン林近傍のソ

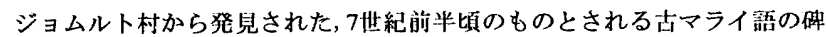
文中にみえる, ヒンドゥー教の熟心な信奉者であるSelendraといら個人の 名を, シャイレーンドラ王朝の南接の祖先に比定することにより，中部ジャ ワ期の統一王朝は唯ー・シャイレーンドラ王朝のみであったとみ, また歴代の 王はヒンドゥー教か仏教のいずれかを選択して信禁し, 改宗の自由む保赫さ れていたとする説も提晿されている (Soekmono, R., Chandi Borobudur, a Monument of Mankind, Paris: Unesco Press, 1976, p. 9)。このような説すら も単なる憶測として哌け得ないといら点に, 中部ジャワ史の解明がいかに難 渋しているかが集約的に装れているといえるだろう。

(19)千原大五郎「中部ジャワのチャンディ建筑に対する編年的考察」『月本建策 学会論文報告集』第 238 号, 1975, p. 135

(20)Soekmono, R., Tjandi Merak, Skripsi Sarjana Universitas Indonesia, Jakarta, 1953, p, 23; Bernet Kempers, A. J., "Prambanan, 1954", Bijdragen tot de Taal-, Land- en Volkenkunde 111, 1955, p.8

(21)Vogler, E. B., "De stichtingstijd van de Tjandi's Gunung Wukir en Badut", Bijdragen tot de Taal, Land- en Volkenkunde 108, 1952, p. 316

(22)Poerbatjaraka, Riwajat Indonesia Djilid I, Djakarta: Jajasan Pembangunan, 1951, pp. 53-55

(23)前揭茟注(21)p. 315

(24)Soekmono, R., "The archaeology of Central Java before 800 A.D.", in R. B. Smith and W. Watson ed., Early South East Asia; Essays in archaeology, history and historical geography, New York, Kuala Lumpur: Oxford University Press, 1979, p. 462

(25)Krom, N. J., Inleiding tot de Hindoe-Javaansche kunst. Vol. I, 's-Gravenhage: Murtinus Nijhoff, [First edition 1920] , 1923, p. 166

(26)Verbeek, R. D. M., Inventaris der Hindoe-oudheden op den grondslag van Dr. R. D. M. Verbeek's Oudheden van Java, in: Rapporten van den Oudheidkundigen Dienst in Nederlandsch-Indië 1915, Batavia: Albrecht, 's-Gravenhage: Martinus Nijhoff, 1918, p. 262

(27)前提蓄注(24)p. 462

(28)前揭惹注(19)p. 135, 138

(29)Dumarçay, J. , Candi Sewu dan arsitektur bangunan agama Buda di Jawa Tengah, Jakarta: Puslit Arkenas, [Originally published in France, Paris: EFEO, 1981; translated by Winarsih Arifin dan Henri Chambert-Loir] , 1986, p. 42

(30)前揭箐注(29)p. 39 の注 3)

(31) 前揭著注(29)p. 6

(32)前揭書注(29)p. 42 の注 14)

(33)前揭書注(29)p. 42

(34)(1)前物菜注(29)p. 39の注3); (2) Dumarçay, J., The temples of Java, Singapore: Oxford University Press, 1986, p. 42

(35)前揭青注(21)pp. 313-346

(36)前揭暂注(24)pp. 462-463

(37)前揭書拄(19)p. 139

(38)Dumarçay, J., Le savoir des maîtres d'œuvre Javanais aux XIIf et XIV siècles, Paris: École Française d'Extrême-Orient, [Mémoires Archéologiques XVII] , 1986, pp. 5-6

(39)Haan, B. De, "Tjandi Badut", Oudheidkundig verslag 1929, Albrecht, 1930 , p. 257

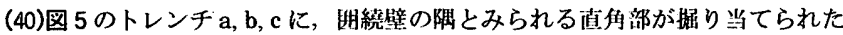
とい 5 Soemarno, A., Laporan Penggalian Pengumpulan Data Candi Badut di Malang, Departemen Pendidikan dan Kebudayaan Kantor Wilayah Propinsi Jawa Timur, Bagian Proyek Pelestarian/Pemanfaatan Peninggalan Sejarah dan Purbakala Jawa Timur, Surabaya, 1992/1993, pp. 14-16の能述 に基ういて，教地中心点の抒抒よその位箸を求めた。

(41)スクモノは，アルジュノの推定建立作次を650 730年頃（前揭留注(24)p.

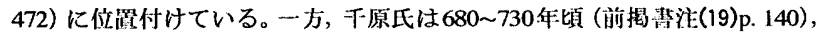
またデュマルセは 750 年頃（能揭皆注:(14)p. 287）としている。

(42)千原大五郎『インドネシア社寺建築史』甘本放送出版帅会, 1975, pp. 99-103 (43)仏教の嗣堂の場合, ラトナの代わりに飾りストゥーパが配せられる等の相邀 はあるが, 基本的にアルジュノの建策構成が祖型になっていると考えること が可能である。また, ジャワのチャンディの平面及び站面の桠成を拊束する梘

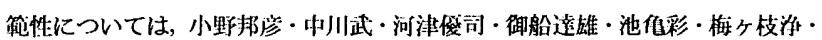
鈴木菜䅹子「チャンティ建築の平面の類型ーインドネシア・チャンディ建筑の 設計方法の研究 ( II )」『日本建勧学会大会学術講演梗概集』，1995, pp. 545-546;

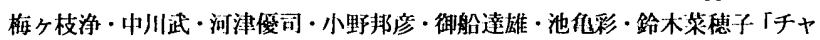
ンディ建筑の方面構成・インドネシア・チャンディ建勧の設汁方法の研究(III-

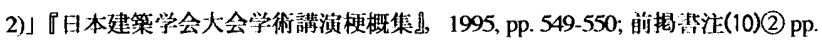
40-45, 51-52を参照のこと。

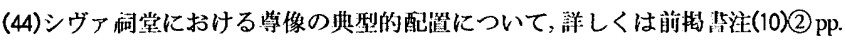
43-44を参照されたい。

(45)しかしながらディエンからは, 出所不部のガネーシャ, ドゥルガー,アガス ティアの像が多数発見されている点は特篚される。

(46)前揭基注:(1)p. 45

(47)前揭珤注(34)(2)p. 14。ディエンのチャンディ・プントデウォから，ヨニ及び ナンディンの像が発見されたことが, オランダ領東インド考古尉による考古

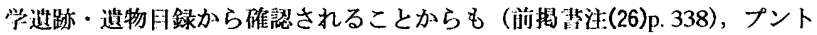
デウオの類例とみられるアルジュノに正対するスマールに,ナンディン像が 交置されていた可能性は十分にあると思われる。

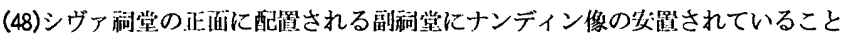
が確認されるのは, グヌン・ウキル，ロロ・ジョングラン，イジョーである。 (49)グドン・ソンゴの邀棰样においては, 曲繶壁の伱在自体が樵認されていない ために, 耐堂样の「ずらし」の有無を判别することはできない。…方, ディ エンに仔する八遗㯇の内, アルジュノ，スリカンディ，プントデウォを除く

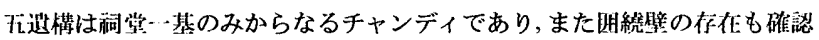
されていない。

(50)(池化彩・中川武・河津俊司・小野扼彦・御船達雄・梅ヶ枝治・鉿木菜䅹子 「チャンディ建策の立面部䧉／モールディングの類型 -インドネシア・チャン ディ建筑の設部方法の研究(III-1)」『日本建策学会大会学術請演梗概集』，1995， p. 547-548; (2) 前抱者注(10)(2) pp. 46-50, pp. 51-52

(51)解揭害注(24)p. 463

(52)(1)普揭皆注(19)pp. 136-137; (2)下原人五郎『東南アジアのヒンドゥー・仏教

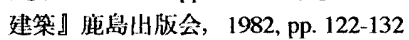

(53)しかしながら下原氏は，クドゥ南部に「北方型」のチャンディが営まれてい た可能性は否定していない（前揭蕒注:(52)(2)p. 131)。

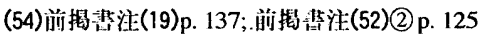

(55)解揭落注(19)p. 137; 前揭显注(52)(2)pp. 123-124

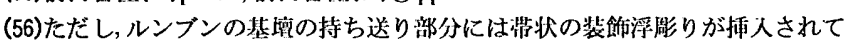
いる点には注意しなければならない。ルンブンの基坟は，反曲綝形以外には

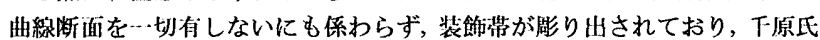

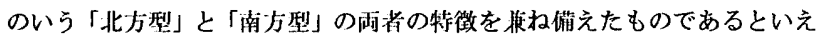
よう。また，プランバナン地域のヒンドゥー教チャンディであるチャン ディ・バロンの基缡も，反曲繰形以外には曲線盽面を有しない一方で，带状 の芘飾りが浮影りされており，これも「北方型」と「南方犁」の混用例とみ るのが妥当であると考えられる。

(57)クドゥ南部の仏教チャンディであるチャンディ・ガウェン(Candi Ngawen)

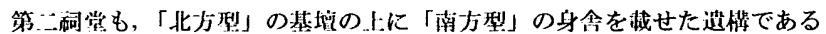
(前揭基注(50)(1) p. 548 参照)。

(58)スクモノは,バドゥの建策全体の構成が占式を残すものとしながらも,グヌ ン・ウキル及びバドゥのカーラ・マカラ装飾を, ディエンのそれと比べて新 しいものとして位罡付けている (Soekmono, R., "Indonesian Architecture of the Classical Period: A Brief Survey", The Sculpture of Indonesia, Washington: National Gallery of Art, 1990, p. 69)。そしてこの点について は, 本文で述べたフォグラーの見解にスクモノは同閶しているといえるだろ 5。こうしたカーラ・マカラ装飾にみる変化は, 筹者が本文で刖らかにした 守院建築栐式の変化に対忘したものとみれば納得が行く。

(59)東部ジャワのマラン近郊にあるチャンディ・バドゥが, 760年の銘あるディ ノヨ啸文を建てた社会集四に帰せられる可能性が商い点は林文中で既に述べ た。そしてチャンディ・バドゥと，クドゥ献部にあって 732 年の建立と推定 されるチャンディ・グヌン・ウキルの建策様式が種々の点で類似し，また 8 世紀の中煩には仏教を奉じるシャイレーンドラ玉朝が中部ジャワ南部に急激 な台頊をみせたことを併せて考虑すれば,シャイレーンドラ王朝の興起に伴 ら政治情等の変化に伴って, ヒンドゥー教勢力の一部が東部ジャワへ移動し た间能性も考えられよう。それと同じように，中部ジャワ北部へと移䄭した ヒンドゥ一教知力のあった可能性も考慮されるべきであろう。

図版出典：[図 2]，[図 6]，[図 8]，[图 9]，[図 12]（1年榣[H大学アジア建筑研

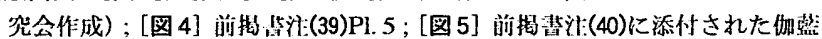

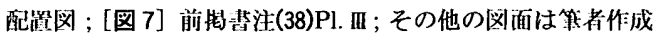

